\title{
PENERAPAN TEKNOLOGI TEPAT GUNA UNTUK PENINGKATAN PEMBERDAYAAN MASYARAKAT DAN LINGKUNGAN
}

\author{
Idha Zaitun Nisa Aryani Zulha \\ Administrasi Publik, Universitas Muhammadiyah Mataram, Indonesia \\ idha.nukman@gmail.com
}

\begin{abstract}
ABSTRAK
Abstrak: Kegiatan ini bertujuan untuk mentransfer pengetahuan dan teknologi pemanfaatan sebagai sumber energi alternatif ramah lingkungan berupa biogas. Dari kegiatan ini, diharapkan masyarakat mendapatkan manfaat sosial dan ekonomis dari limbah yang dihasilkannya sendiri. Metode yang digunakan dalam pelaksanaan kegiatan ini adalah diskusi, penyuluhan, dan eksperimen diversifikasi usaha. Dengan adanya kegiatan ini diharapkan mampu mengubah kebiasaan masyarakat untuk beralih dengan memanfaatkan biogas sebagai energi alternatif yang lebih ramah lingkungan, serta menambah wawasan masyarakat dalam memanfaatkan limbah dan pola hidup yang lebih sehat khususnya untuk menjaga kelestarian alam. Dari keseluruhan rangkaian kegiatan pengabdian, sambutan masyarakat sangat baik dan antusias untuk membantu terlaksananya kegiatan pengabdian. Hal ini terbukti dengan tingkat partisipasi masyarakat yang tinggi serta kesediaan warga untuk mendukung terlaksananya kegiatan ini. Masalah yang dihadapi di lapangan adalah terbatasnya pengetahuan, teknologi dan peralatan produksi untuk menghasilkan kompos yang berkualitas karena belum adanya teknologi tepat guna pembuatan biogas yang dikuasai masyarakat. Pemecahan masalah yang dapat dilakukan dengan pendampingan yaitu memberikan pengetahuan, pemahaman, dan pelatihan.

Kata kunci: Pemberdayaan Masyarakat; Pendampingan dan Manajemen Lingkungan; Biogas dan Diversifikasi.

Abstract: This activity aims to transfer knowledge and utilization technology as an environmentally friendly alternative energy source in the form of biogas. From this activity, it is hoped that the community will get social and economic benefits from the waste that they produce themselves. The method used in the implementation of this activity is discussion, counseling, and business diversification experiments. With this activity, it is expected to be able to change people's habits to switch to using biogas as an alternative energy that is more environmentally friendly, as well as increase people's insight in utilizing waste and healthier lifestyles, especially to preserve nature. From the whole series of community service activities, the response from the community was very good and enthusiastic to help carry out community service activities. This is proven by the high level of community participation and the willingness of citizens to support the implementation of this activity. The problem faced in the field is the limited knowledge, technology and production equipment to produce quality compost due to the absence of appropriate technology for the production of biogas that is controlled by the community. Problem solving that can be done with assistance is to provide knowledge, understanding, and training.
\end{abstract}

Keywords: Community Empowerment; Environmental Assistance and Management; Biogas and Diversification. 


\section{A. LATAR BELAKANG}

Teknologi merupakan hal penting di era modern ini, mengingat kondisi alam sekitar atau masyarakat sudah banyak beralih kepada teknologi (Muzaini, 2014). Berbagai bentuk, jenis, dan sifat Teknologi Tepat Guna (TTG) disalurkan kepada masyarakat guna mempermudah dalam melaksanakan tugas dan aktivitas sehari-hari (Syarifuddin, 2014). Salah satu TTG yang disalurkan kepada masyarakat adalah Biogas. Biogas merupakan gas yang dihasilkan oleh aktivitas anaerobik atau fermentasi dari bahan-bahan organik termasuk di antaranya; kotoran manusia dan hewan, limbah domestik (rumah tangga), sampah biodegradable atau setiap limbah organik yang biodegradable dalam kondisi anaerobic (Subekti, 2011).

Kegiatan ini diadakan di dusun Brau dengan melihat lokasinya yang merupakan salah satu hulu sumber air Brantas yang memiliki potensi pencemaran yang diakibatkan dari kotoran sapi yang melimpah dan pembuangannya yang hanya dibuang diselokan tanpa perhatian lebih. Selain itu Brau merupakan salah satu dusun yang masuk dalam rencana program bina desa oleh Pemerintah Kota Batu. Lokasinya juga merupakan kawasan yang jauh dari dusun-dusun lain dan jauh dari akses transportasi umum sehingga perkembangan ekonominya kurang berkembang.

Brau sendiri terkenal sebagai lokasi pengembangan ternak sapi perah. Sekitar 90 persen penduduk dusun Brau adalah peternak sapi perah, tidak heran dusun Brau ini menjadi salah satu dusun yang memiliki produksi susu terbesar di Desa Gunungsari dan menjadi lokasi sumber pemasukan susu di kota Batu. Di dusun Brau memiliki populasi ternak lebih besar dari jumah penduduknya. Hal ini menyebabkan peternak sapi perah membutuhkan luasan lahan hijau yang cukup besar. Karena itu pemanfaatan lahan bukit-bukit sebagai area penanaman rumput gajah yang menjadi makanan dominan sapi perah dusun ini yang berakibat pada kurangnya lahan hijau yang beralih fungsi menjadi ladang rumput gajah. Sebelumnya di area sekitar Brau pernah dilakukan reboisasi pohon dari pemerintahan kota Batu untuk menghindari longsor yang diakibatkan kurangnya tanaman penyerap air karena wilayah ini termasuk wilayah potensi rawan bencana longsor.

Dalam keseharian peternakan sapi perah ini, ternak sapi warga Brau mengeluarkan limbah berupa feces dan urine secara kontinue dengan jumlah yang melimpah. Lokasi penampungan kotoran sapi ini hanya dibuang dibelakang rumah dan tercampur dengan air selokan mereka yang bermuara di sungai Brantas Malang. Seperti yang diketahui limbah kotoran sapi yang menggandung gas methana $(\mathrm{CH} 4)$ merupakan sumbangsi terbesar pada polusi udara, air, dan tanah daripada asap kendaraan bermotor di daerah berkembang yang bermuara pada Global Warming. Pengetahuan akan lingkungan baik dampak limbah organik, cara pengolahan limbah yang benar, dan kesadaran masyarakat baik dari anak-anak sampai dewasa dirasa kurang dikarenakan hal ini telah menjadi kebiasaan yang lama dilakukan.

Selain itu, segi perekonomian masyarakat berpengaruh pada cara kerja masyarakat Brau dalam mengolah alam. Kesibukan dalam merawat sapi dan pemenuhan makananannya, mengakibatkan kurang dilihatnya nilai lebih dari hasil limbah kotoran maupun olahan kreatif dari sapi tersebut. Padahal jika dihitung, penyediaan perawatan sapi tidak sebanding dengan hasil yang diperoleh hanya dengan susu. Sedangkan dari fasilitas umum yang berada di 
dusun ini kurang mendapat perhatian lebih dari masyarakat dan pemerintah desa seperti halnya kamar mandi umum, lampu jalan, dan fasilitas posyandu.

Adapun tujuan pelaksanaan kegiatan ini untuk (1) Meningkatkan kesadaran, kepedulian, dan pengetahuan masyarakat akan pentingnya menjaga fungsi lingkungan hidup (2) Membantu meningkatkan fungsi lingkungan hidup dengan penggunaan teknologi yang tepat (3) Menciptakan peluang ekonomi baru dengan memanfaatkan sumberdaya yang ada.

\section{B. METODE PELAKSANAAN}

\section{Gambaran Mitra Kegiatan}

Mayarakat dusun Brau merupakan masyarakat yang masih bersifat homogen secara keseluruhan. Sifat kekeluargaan dan gotong royong masih sering dilakukan di dusun ini baik dalam pembersihan lingkungan, hajatan, bahkan membantu secara ekonomi. Dalam masalah ekonomi, masyarakat Brau berada di kisaran menengah kebawah dengan topangan hidup yang mengandalkan hasil pertanian dan perah susu yang disetorkan di 2 KUD yang ada di dusun ini. Kebanyakan masyarakat Brau bermata pencaharian sebagai petani ladang dan peternak sapi perah, sehingga kebanyakan waktu dihabiskan diladang dan mencari rumput. Untuk perdagangan, jarang masyarakat bermata pencaharian ini karena dari segi waktu, dana, dan lokasi yang tidak menunjang kearah perbaikan ekonomi mereka.

Waktu kerja bagi pemelihara ternak sapi, di mulai pukul sekitar pukul 03.00 pagi dan berakhir pada pukul 18.00 malam. Pada pagi hari para peternak mulai memerah susu sapi pada pukul 05.00 pagi sampai pukul 06.00 pagi. Setelah itu, para peternak bekerja mencari rumput gajah untuk pakan ternak mereka sampai pukul 15.00 sore. Pukul 17.00 peternak kembali memerah susu sapi untuk disetorkan ke KUD susu. Sementara harga susu sapi perah hanya berkisar Rp. 4000,-- per liter.

\section{Bentuk Kegiatan}

\section{a. Pembuatan Instalasi Biogas}

Pembuatan instalasi Biogas menjadi salah satu alternatif yang tepat dalam pengurangan polusi lingkungan yang ramah lingkungan dan ekonomis jangka panjang. Biogas direncanakan akan dibangun pada warga yang bersedia dan disekitaran rumah warga yang memiliki ternak sapi. Pembuatan instalasi Biogas akan dilaksanakan baik secara komunal maupun individual sesuai dengan jumlah sapi dalam satu lokasi dan kesepakatan yang telah disetujui sebelumnya. Pembuatan instalasi Biogas ini bekerja sama dengan Yayasan Rumah Energi melalui program BIRU (Biogas Rumah) dan Yayasan Alam Bumi Lestari (YABULE).

\section{b. Penyuluhan Masyarakat}

Penyuluhan direncanakan diberikan kepada masyarakat baik yang dalam masa pendidikan maupun masyarakat secara umum. Penyuluhan berupa pemberian materi tentang lingkungan hidup dengan cara-cara kreatif yang akan dilakukan terhadap siswa-siswa Taman Kanak-kanak (TK), Sekolah Dasar (SD), dan Sekolah Menengah Pertama (SMP) yang berada di sana. Penyuluhan juga akan dilakukan terhadap masyarakat secara umum melalui adanya pendekatan secara aktif dan partisipatif dalam kehidupan sehari-hari masyarakat. 


\section{c. Diversifikasi Usaha Rakyat}

Waktu bekerja para peternak hampir tidak sebanding dengan penghasilan yang mereka dapatkan. Untuk itu, perlu adanya inovasi pengolahan susu menjadi produk jadi yang dapat meningkatkan nilai jual dan dapat menambah pendapatan masyarakat dusun Brau. Pembuatan olahan susu berupa dodol dan kerupuk susu ini lebih diarahkan ke ibuibu rumah tangga yang lebih banyak menghabiskan waktu di rumah. Selain itu dengan pengolahan dodol dan krupuk cukup mudah dan tidak banyak membutuhkan waktu lama dan biaya banyak.

3. Hasil Yang Diharapkan

a. Masyarakat dapat memanfaatkan teknologi tepat guna yang ramah lingkungan.

b. Adanya alternatif pengembangan usaha rakyat yang inovatif.

c. Adanya perubahan sikap masyarakat menjadi peduli dan sadar akan pentingnya menjaga lingkungan.

\section{Indikator Keberhasilan}

a. Terbangunnya minimal 1 instalasi BIOGAS \& menyala sempurna.

b. Adanya diversifikasi usaha oleh masyarakat selain matapencaharian utama yang bersifat berkelanjutan.

c. Partisipasi masyarakat secara keseluruhan dalam kegiatan ini minimal 30 persen dari populasi warga Dusun Brau.

\section{HASIL DAN PEMBAHASAN}

\section{Pembuatan Instalasi Biogas}

a. Pembuatan 1 instalasi biogas dan menyala sempurna telah sesuai dengan indikator kegiatan ini. Biogas sendiri bisa dimanfaatkan oleh keluaga Bpk Wahono, Bpk Sarijo, dan Bpk Arif. Dalam pembangunannya sampai menyala sempurna dibutuhkan 2 bulan yaitu bulan Juli-Agustus 2014 Pasca Pembangunan di mulai pada bulan September sampai sekarang. Untuk bentuk paska ini lebih pada kegiatan Monitoring dan Evaluasi yang dilakukan baik pada pengelolaan BIOGAS, pemanfaatan BIOGAS yang sudah dirasa oleh user dalam pemenuhan kebutuhan rumah tangga, penarikan kontribusi user juga sudah terlaksana sebanyak $2 \mathrm{x}$ yaitu bulan Oktober \& November 2014, pemanfaat hasil limbah BIOGAS dengan penggunaan pupuk bioslury untuk perladangan, dan silaturahmi rutin.

b. Manfaat Biogas sejauh ini masih dalam penambahan bahan bakar dan bahan baku pupuk dikarenakan kebutuhan sehari-hari yang besar dari user, tetapi rutin perawatan, inisiatif, dan tepat waktu dalam penarikan kontribusi menjadi indikator kemandirian user dan tanggung jawab mereka dalam mengolah Instalasi Biogas yang sudah dibuat. 


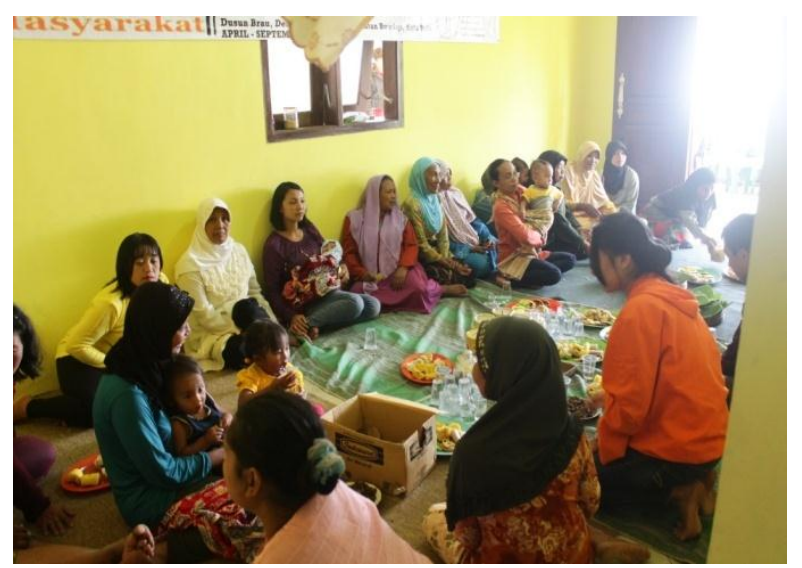

Gambar 1. Partisipan Masyarakat Dalam Peresmian Biogas

Tabel 1. Partisipan Peresmian Biogas, Cek Kesehatan Gratis dan Pengenalan Produk

\begin{tabular}{lccc}
\hline \multicolumn{1}{c}{ Partisipan } & Biogas & Penyuluhan & Diversifikasi Produk \\
\hline Warga Brau & 73 & 42 & 11 \\
\hline Anak-anak & \multicolumn{4}{c}{46} & \\
\hline User & 10 & & \\
\hline LPKP & 4 & & \\
\hline EM & 2 & & \\
\hline BIRU & 2 & & \\
\hline UB & 2 & & \\
\hline Pamong Desa & 2 & & \\
\hline Karang Taruna & & 30 & 12 \\
\hline LAKESMA & & 6 & \\
\hline Mobil Pintar & & 3 & \\
\hline MAPALA & 12 & & \\
\hline Rumah Yoghurt & & & \\
\hline \multicolumn{1}{c}{ Total } & 107 & 127 & \\
\hline
\end{tabular}

\section{Penyuluhan Lingkungan dan Kesehatan}

Penyuluhan Kesehatan dan Lingkungan telah terlaksanakan dengan partisipasi dan penerima manfaat dari warga Brau sendiri sehingga menanamkan sikap peduli dan sadar akan lingkungan dan kesehatan masyarakat. Kegiatan ini memang lebih terfokus pada anak-anak dengan ragam kegiatan yang dibuat dengan materi sebagai berikut :

Tabel 2. Materi Penyuluhan

\begin{tabular}{lcll}
\hline No & Kegiatan & \multicolumn{2}{c}{ Materi } \\
\hline \multirow{2}{*}{1} & Penyuluhan I & $\begin{array}{l}\text { Materi yang disampaikan berupa kegiatan kerja } \\
\text { bakti menjaga kebersihan lingkungan dan } \\
\text { kebiasaan mencuci tangan kepada anak-anak }\end{array}$ \\
\hline \multirow{3}{*}{$\begin{array}{l}\text { Pelestarian lingkungan dan kebiasaan mencuci } \\
\text { tangan dan gosok gigi pada tanggal 29 Juni 2014 }\end{array}$} \\
& $\begin{array}{l}\text { melalui materi formal dan pemutaran film. } \\
\text { Kegiatan ini diawali dengan sosialisasi kepada } \\
\text { anak-anak disana sebagai bentuk pengenalan dan } \\
\text { pemberitahuan adanya kegiatan penyuluhan di }\end{array}$ \\
\hline
\end{tabular}


Idha Zaitun, Penerapan Teknologi Tepat Guna...

\begin{tabular}{|c|c|c|}
\hline & & Dusun Brau \\
\hline 3 & Penyuluhan III & $\begin{array}{l}\text { Pengaplikasian materi forum yang telah } \\
\text { disampaikan pada keluar lapang penyuluhan } \\
\text { sebelumnya. Materi pada kegiatan ini berupa } \\
\text { penjagaan kebersihan lingkungan, penanaman } \\
\text { pohon, dan kebiasaan mencuci tangan. }\end{array}$ \\
\hline 4 & Penyuluhan VI & $\begin{array}{l}\text { Pematerian dan pengaplikasian mencuci tangan } \\
\text { dan gosok gigi yang baik sendiri dan sebagai review } \\
\text { penanaman wacana hidup sehat pada anak usia } \\
\text { dini }\end{array}$ \\
\hline 5 & Penyuluhan V & $\begin{array}{l}\text { Pemasangan } 6 \text { plang himbauan hidup bersih } \\
\text { dengan pengusahaan keterlibatan anak-anak Brau } \\
\text { sebagai bentuk aplikasi cinta lingkungan }\end{array}$ \\
\hline 6 & Penyuluhan IV & $\begin{array}{l}\text { Pemberian fasilitas perpustakaan keliling sebagai } \\
\text { sarana membaca anak-anak dan pemberan cek } \\
\text { kesehatan gratis bekerjasama dengan civitas } \\
\text { akademik UB }\end{array}$ \\
\hline
\end{tabular}

Tabel 3. Penyuluhan Lingkungan dan Kesehatan

\begin{tabular}{|c|c|c|}
\hline Penjalanan & Kendala & Rekomendasi \\
\hline $\begin{array}{l}\text { Materi penyuluhan lingkungan } \\
\text { dan kesehatan pada anak-anak di } \\
\text { tingkat pendidikan formal } \\
\text { (Sekolah Dasar) penjalanannya } \\
\text { tidak dilakukan. Tetapi dilakukan } \\
\text { penyuluhan secara informal } \\
\text { dalam setiap kunjungan untuk } \\
\text { mengajak } \\
\text { membersihkan anak-anak } \\
\text { sekitarnya. }\end{array}$ & $\begin{array}{lr}\text { Kurangnya } & \\
\text { koordinasi } & \text { waktu } \\
\text { dengan } & \text { beberapa } \\
\text { pihak } & \end{array}$ & $\begin{array}{l}\text { Koordinasi } \\
\text { dengan } \\
\text { pihak } \\
\text { sekolah } \\
\text { dasar lebih } \\
\text { awal/jauh- } \\
\text { jauh hari } \\
\text { sebelumnya. }\end{array}$ \\
\hline $\begin{array}{l}\text { Diadakan materi Penyuluhan } \\
\text { Lingkungan pada Masyarakat } \\
\text { Umum tidak dilaksanakan, dan } \\
\text { sebagai gantinya diadakan bentuk } \\
\text { pendekatan persuasif terhadap } \\
\text { kondisi kesehatan warga melalui } \\
\text { cek kesehatan gratis. Tetapi tidak } \\
\text { mengurangi antusiasme } \\
\text { masyarakat dusun Brau untuk } \\
\text { tetap mengikuti kegiatan } \\
\text { penyuluhan kesehatan dalam } \\
\text { bentuk cek kesehatan gratis, bisa } \\
\text { dilihat dari kehadiran warga } \\
\text { dusun Brau yang hadir untuk cek } \\
\text { kesehatan gratis. }\end{array}$ & $\begin{array}{l}\text { Kurang } \\
\text { mengerucutnya } \\
\text { permasalahan } \\
\text { tentang lingkungan } \\
\text { di lokasi pengabdian } \\
\text { masyarakat sehingga } \\
\text { sulit mendatangkan } \\
\text { pemateri dibidang } \\
\text { tersebut. }\end{array}$ & $\begin{array}{l}\text { Lebih } \\
\text { mengerucut } \\
\text { kan } \\
\text { masalah } \\
\text { lingkungan } \\
\text { yang } \\
\text { terdapat di } \\
\text { lokasi } \\
\text { pengabdian } \\
\text { masyarakat }\end{array}$ \\
\hline
\end{tabular}




\section{Diversifikasi Produk}

\section{a. Diversifikasi Produk Olahan Susu}

Produk olahan turunan susu dibuat atas nama kelompok tani Margomulyo, Dusun Brau dengan dampingan dan partipasi aktif tim. Produk olahan turunan susu dalam proses percobaan dilakukan pada bulan April sampai Desember sebanyak 5 kali \& diperkenalkan pada masyarakat melalui kegiatan besar pertanian dan peternakan pada acara "Gebyar Kuliner Nusantara dan Produk Unggul Kota Batu 2014" dengan produk susu pada tanggal 16-17 Mei 2014, dan "Pekan Nasional Petani Nelayan XIV tahun 2014" di stadium Kanjuruhan Kepanjen Malang pada tanggal 7-12 Juni 2014 dengan label kelompok tani Margomulyo \& Dinas Peternakan dan Pertanian kota Batu dengan produk berupa dodol susu, pie susu, dan pie apel. Pada bulan September - November 2014 dilakukan percobaan dan pengujian lab untuk melihat kadar dan kualitas produk dodol susu, tetapi hasil yang diperoleh masih harus dilakukan percobaan dan uji lab terakhir terakhir untuk syarat pensertifikatan halal dan siap di pasarkan dan pembuatan label.

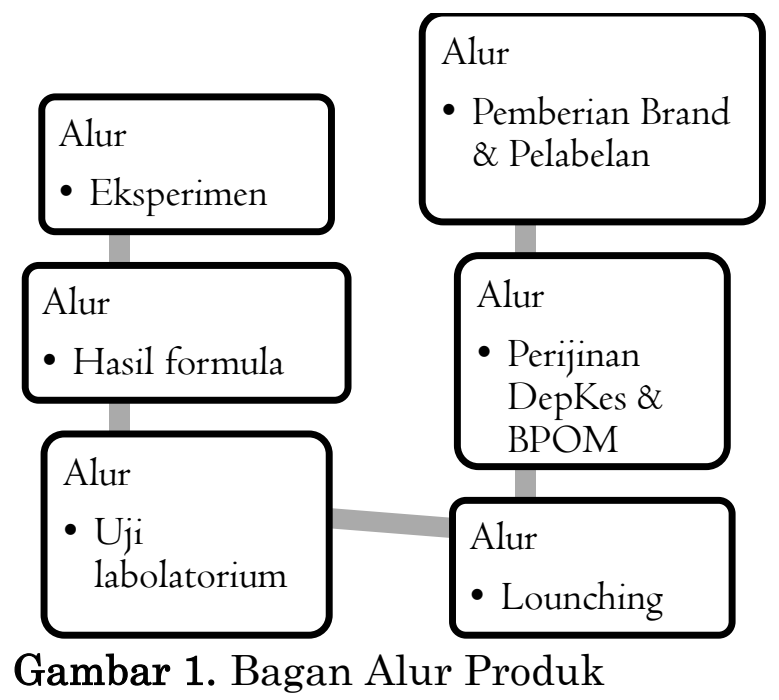

Partisipasi warga Brau ada 203 orang dari keseluruhan 494 jiwa warga dusun Brau RT 04 \& 05 dan 33 pihak eksternal.

\section{SIMPULAN DAN SARAN}

Simpulan yang kami dapatkan dalam kegiatan ini adalah kegiatan pengabdian kepada masyarakat di Dusun Brau, Desa Gunungsari, Kecamatan Bumiaji Kota Batu mendapat tanggapan dan perhatian yang cukup baik dari warga sekitar dan beberapa partisipan yang terlibat. Program kegiatan yang diberikan kepada masyarakat dapat terealisasi dengan optimal dan lancar, bekal yang diberikan kepada masyarakat pada dasarnya, memberikan dukungan dan pengetahuan yang berdampak dampak positif, kegiatan pengabdian kepada masyarakat mempunyai tujuan di antaranya menjalin erat hubungan antara lembaga perguruan tinggi sebagai sumber ilmu pengetahuan dengan masyarakat dan pemerintah setempat terintegrasi dengan baik.

Sedangkan saran yang dapat kami berikan yaitu pembuatan biogas kedepannya bisa ditindak lanjuti dalam hal monitoring dan evaluasi agar menjadi referensi bentuk kegiatan dengan tujuan dan sasaran serupa. Untuk 
kegiatannya sendiri yaitu pengelolahan limbah yang dihasilkan (Bioslury) yang berpotensi untuk dimanfaatkan pihak penerima manfaat. Kemudian dalam kegiatan penyuluhan lingkungan dan kesehatan mayarakat perlu adanya arahan secara berkelanjutan agar dikembangkan di media formal dan pemfokusan penerima manfaat. Dalam kegiatan diversifikasi produk dodol susu dilihat dari hasilnya dapat menjadi salah satu peluang penunjang usaha masyarakat dan kesanggupan kelompok masyarakat untuk menindaklanjutinya dengan bentuk pendampingan pengolahan dodol susu oleh penerima manfaat secara mandiri.

\section{DAFTAR RUJUKAN}

Kartini, N. L. and Suranjaya, I. G. (2018) 'Pengolahan Eceng Gondok (Eichhornia Crassipes) Untuk Peningkatan Pendapatan Masyarakat Dan Pelestarian Danau Buyan Di Desa Pancasari Kecamatan Sukasada Kabupaten Buleleng Propinsi Bali', Buletin Udayana Mengabdi, 17(2), p. 16. doi: 10.24843/bum.2018.v17.i02.p03.

Litbang, J. et al. (2015) 'Opportunities of Biogas Development in Dairy Cattle Center Areas', Peluang Pengembangan Biogas Di Sentra Sapi Perah, 32.

Mulyatun, M. (2016) 'Sumber Energi Terbarukan dan Pupuk Organik dari Limbah Kotoran Sapi', Dimas: Jurnal Pemikiran Agama untuk Pemberdayaan, 16(1), p. 191. doi: 10.21580/dms.2016.161.898.

Muzaini, M. (2014). Perkembangan Teknologi Dan Perilaku Menyimpang Dalam Masyarakat Modern. Jurnal Pembangunan Pendidikan: Fondasi Dan Aplikasi, 2(1). https://doi.org/10.21831/jppfa.v2i1.2617

Subekti, S. (2011). Pengolahan limbah cair tahu menjadi biogas sebagai bahan bakar alternatif. Prosiding Seminar Nasional Sains Dan Teknologi Ke-2, (1), 61-66.

Syarifuddin, S. (2014). Literasi Teknologi Informasi dan Komunikasi. Jurnal Penelitian Komunikasi, 17(2). https://doi.org/10.20422/jpk.v17i2.14

Wahyuni, S. (2017) 'Menghasilkan Biogas dari Aneka Limbah', Agromedia, pp. 1-7.

Yanti, D. and Arlius, F. (2018) 'Pemberdayaan Masyarakat Tani Melalui Pengembangan Teknologi Biogas Dengan Pemanfaatan Limbah Pertanian Sebagai Sumber Energi Alternatif Pedesaan', Jurnal Pengabdian Kepada Masyarakat, 24(1), p. 537. doi: 10.24114/jpkm.v24i1.8946. 